Sains Malaysiana 50(12)(2021): 3765-3772

http://doi.org/10.17576/jsm-2021-5012-25

\title{
The High Occurrence of Multidrug-Resistant Salmonella spp. Isolated from Raw Chicken Meat and Contact Surfaces at Wet Market in Malaysia
}

(Kekerapan Kejadian Salmonella spp. Rintang Pelbagai Antibiotik Dipencilkan daripada Daging Ayam Mentah dan Permukaan Bersentuhan di Pasar Basah Malaysia)

\author{
Asif Sukri, Siti Shahara Zulfakar, Illya Syahirah MOHD TAIB, Nurul Fathiah OMAR \& NoraZIAH \\ MOHAMAD ZIN*
}

\begin{abstract}
Post-slaughter processing steps during poultry meat production contribute to Salmonella contamination and may transmit multidrug-resistant Salmonella to chicken meats and contact surfaces. This study was undertaken to identify Salmonella spp. strains isolated from chicken meats and their contact surfaces, and to determine their antibiotic resistance profiles. A total of 20 samples were collected from raw chicken meat and its contact surfaces from a shop in Pasar Chow Kit, Kuala Lumpur. Identification of presumptive Salmonella colonies was conducted by using biochemical tests and multiplex polymerase chain reaction (PCR). Antibiotic susceptibility test was conducted by using Kirby-Bauer disk diffusion method against 11 antibiotics. Salmonella enterica Group I was only detected in seven samples. The antibiogram testing showed that all the seven Salmonella isolates (100\%) were multidrug-resistant and all isolates were resistant to penicillin, chloramphenicol, erythromycin, and tetracycline. Resistance towards trimethoprim-sulfamethoxazole, amoxicillin and ampicillin was observed in four isolates. However, sensitivity was recorded for cephalexin, cefoxitin, cefotaxime, and ceftriaxone in six isolates. The highest multiple antibiotic resistance (MAR) index of 1.00 (resistance to all eleven antibiotics tested) was observed in one isolate (P2) while the lowest MAR index of 0.36 (resistance to four antibiotics tested) was observed in three isolates (CB, M2 and M3). Our results demonstrated that raw chicken and meat contact surface were a source of multidrug-resistant Salmonella and can contribute to significant health concern in Malaysia. Stringent hygienic procedure during chicken meat processing should be therefore be practised.
\end{abstract}

Keywords: Antibiotic susceptibility; multidrug-resistant Salmonella; raw chicken meat; Salmonella spp.; wet market

\section{ABSTRAK}

Langkah pasca penyembelihan semasa pemprosesan daging ayam menyumbang kepada pencemaran dan penularan Salmonella yang rintang terhadap pelbagai antibiotik dalam daging ayam pada permukaan yang bersentuhan. Kajian ini telah dijalankan untuk mengenal pasti strain Salmonella spp. yang dipencilkan daripada daging ayam dan daripada permukaan bersentuhan dan seterusnya digunakan untuk menentukan profil kerintangan antibiotik. Sejumlah 20 sampel telah diambil daripada daging ayam mentah dan permukaan bersentuhan daripada sebuah kedai di pasar basah Chow Kit yang terletak di Kuala Lumpur. Pengenalpastian koloni Salmonella telah dijalankan menggunakan ujian biokimia dan tindak balas polimerase berantai (PCR). Ujian kerentanan antibiotik telah dilakukan menggunakan kaedah resapan piring Kirby-Bauer terhadap 11 antibiotik. Salmonella enterica Kumpulan I telah dikesan dalam tujuh sampel. Ujian antibiogram menunjukkan semua pencilan Salmonella rintang terhadap pelbagai antibiotik dan semua pencilan rintang terhadap Penisilin, Kloramfenikol, Eritromisin dan Tetrasiklin. Kerintangan terhadap Trimetoprim-Sulfametoksazol, Amoksilin dan Ampisilin diperhatikan dalam empat pencilan Salmonella. Namun, empat pencilan tersebut rentan terhadap Sefalekin, Sefositin, Sefotaksim dan Seftriakson. Indeks kepelbagaian rintangan antibiotik (MAR) paling tinggi iaitu 1.00 (rintang terhadap sebelas antibiotik yang diuji) telah diperhatikan dalam satu pencilan (P2) manakala indeks MAR paling rendah iaitu 0.36 (rintang terhadap empat antibiotik) diperhatikan dalam tiga pencilan (CB, M2 dan M3). Hasil kajian menunjukkan daging ayam mentah dan permukaan bersentuhan dengan daging merupakan sumber Salmonella rintang terhadap pelbagai antibiotik dan boleh menyumbang kepada masalah kesihatan di Malaysia. Prosedur kebersihan yang ketat semasa pemprosesan daging ayam perlu diamalkan.

Kata kunci: Daging ayam mentah; Salmonella spp.; Salmonella rintang pelbagai antibiotik; pasar basah; ujian kerentanan antibiotik 


\section{INTRODUCTION}

Meat is an essential protein source that provides nutrients such as important amino acids, B complexes, vitamins and minerals and is a suitable habitat for bacterial growth (Abdalla et al. 2009). Chicken are the major types of poultry meat consumed which account for about twothirds of the world's total production (Mead 2000). In Malaysia, the total production of poultry in 2019 was estimated to be around 1651.5 metric tonnes with 50.7 $\mathrm{kg}$ consumption per capita (Department of Veterinary Services Malaysia 2020). Consumption of chicken meats in Malaysia is high because there is no religious meat restriction among the local population, especially among the major ethnicities in Malaysia (Jayaraman et al. 2013).

Salmonella, a member of the Enterobacteriaceae family, is a significant pathogen in foodborne illness (Montville \& Matthews 2008). To date, nearly 2463 serotypes of Salmonella have been discovered (Najwa et al. 2015). It is estimated that Salmonella infection causes 155, 000 deaths annually worldwide (Li et al. 2017; Majowicz et al. 2010). The most prevalent serotypes are nontyphoidal salmonellosis or enterocolitis caused by at least 150 Salmonella serotypes of Salmonella Typhimurium and Salmonella Enteritidis. These organisms are ingested by unhygienic production of raw or contaminated food products. Salmonellosis clinical signs include sudden onset of fever, stomach pain, diarrhoea, nausea, and vomiting (Crump et al. 2015).

In wet market, common food contact surfaces can include working tables, cutting knives, chopping board and utensils for holding water i.e. metal buckets or plastic containers. This food handling device must be maintained in a safe condition that minimizes the risk of contamination of foods to avoid cross contamination (Ishola \& Taiwo 2014). Meat contact surfaces are usually contaminated with pathogens from the intestinal tract, feet and feathers of animals. Combination of contaminated food contact surfaces and low hygienic practices by the food handlers increases the risk for a foodborne disease (Zulfakar et al. 2018). Proper handling of poultry meat is important in order to ensure hygienic monitoring of processed meat and meat contact surfaces in retail production (Saad et al. 2011).

Salmonella has demonstrated increased resistance to first-line antibiotics used to treat salmonellosis, including chloramphenicol, trimethoprim-sulfamethoxazole, ampicillin and new generation of antibiotics, such as cephalosporins and quinolones, leading to limited treatment choices and increased economic burden (Muhammad et al. 2020; Su et al. 2004). The rise of antibiotic-resistant Salmonella via zoonotic transmission has become a threat to public health (Sallam et al. 2014).
The objectives of this study were undertaken to identify and determine the profile of Salmonella spp. antibiotic susceptibility obtained from fresh chicken meat and contact surfaces.

\section{MATERIALS AND METHODS}

\section{SAMPLE COLLECTION}

Samples were collected from wet market located at Chow Kit, Kuala Lumpur, which is one of the main wet markets in Kuala Lumpur, Malaysia. The Chow Kit wet market is a popular wet market in Kuala Lumpur where shoppers can obtain fresh meats and fruits. It is also popular among Muslim community where they can obtain 'halal' meat from the market. The process of slaughtering animals to meat processing are usually conducted in the market according to Syariah law. Collection of meat contact surface samples were conducted as previously described by Zulfakar et al. (2018). In general, sterile sponge swabs (3M, USA) were moistened with sterile buffered peptone water (Merck, Darmstadt, Germany). The contact surfaces were then swabbed again for the second time with a dry sponge. Sponge swab samples were then kept in sterile plastic bags containing $25 \mathrm{~mL}$ buffered peptone water. Among surface contact items sampled in this study include tables $(n=3)$, cutting knives $(n=5)$, chicken cages used to hold chicken prior to slaughter $(n=2)$, de-feathering machine $(n=1)$, water for rinsing chicken meat $(n=1)$, chicken meat container $(n=1)$, and cutting boards $(n=4)$. Chicken meat samples were collected from parts of the wing $(n=1)$, drumstick $(n=1)$ and breast $(n=1)$. Overall, 20 samples were collected from raw chicken meat and contact surfaces from one vendor. All samples were kept in an ice box and sent to the laboratory to be processed within the same day.

\section{DETECTION OF Salmonella spp.}

In the laboratory, a total of $25 \mathrm{~g}$ chicken meat was excised from each chicken parts and put inside stomacher bags containing $225 \mathrm{~mL}$ buffered peptone water. Chicken meat and sponge swab samples were then homogenised using a stomacher for $3 \mathrm{~min}$. Ten $\mathrm{mL}$ of the homogenised samples were taken from each sample bags and incubated for 18 to $20 \mathrm{~h}$ at $37{ }^{\circ} \mathrm{C}$ as a pre-enrichment step. An aliquot of $0.1 \mathrm{~mL}$ pre-enrichment medium from each sample was then aseptically transferred into the universal bottle containing $10 \mathrm{~mL}$ Rappaport-Vassiliadis broth (RVS) (Oxoid, Basingstoke, UK) and incubated for 18 to $24 \mathrm{~h}$ at $41^{\circ} \mathrm{C}$. A loopful of enriched suspension was then streaked on selective media of xylose lysine deoxycholate agar (XLD) (Oxoid, Basingstoke, UK), followed by incubation 
for $24 \mathrm{~h}$ at $37^{\circ} \mathrm{C}$. Presence of Salmonella colonies was reported as present or absent (Chong et al. 2017).

\section{CONFIRMATION OF Salmonella spp. ISOLATES}

Presumptive Salmonella colonies which displayed black colonies on XLD agar plates were Gram-stained and subjected to the following conventional biochemical tests: triple sugar iron, methyl red, Voges-Proskauer, citrate, motility, urease and indole production. All presumptive Salmonella colonies were then identified by using Microgen GN-ID (GNA+B) system (Microgen Bioproducts Ltd, UK).

\section{IDENTIFICATION OF Salmonella spp. VIA POLYMERASE CHAIN REACTION (PCR)}

After a series of biochemical test, presumptive Salmonella spp. isolates were grown to logarithmic phase in Muller-Hinton broth (Oxoid, Basingstoke, UK) at $37{ }^{\circ} \mathrm{C}, 120 \mathrm{rpm}$ incubator overnight. DNA extraction was conducted by using the boiling method (Chai et al. 2007).

List of primers used in this study is shown in Table 1. Primers ST11 and ST15 were used for detection of Salmonella spp. by targeting random sequence. For detection of $S$. Enteritidis, primers ENTF an ENTR were used to amplify $S d f I$ gene while for detection of $S$. Typhimurium, primer set Fli15 and Typ04 was employed to amplify $f l i C$ gene. DNA amplification was performed in $25 \mu \mathrm{L}$ reaction mixtures containing $2 \mu \mathrm{L}$ DNA template, $5 \mu \mathrm{L} 5 \times$ PCR buffer (First Base Asia, Singapore), $0.5 \mu \mathrm{L} 10 \mathrm{~m} M$ deoxynucleotide triphosphate (First Base Asia), $2.5 \mu \mathrm{L} 25 \mathrm{mM} \mathrm{MgCl}$ (First Base Asia), $0.5 \mu \mathrm{L}(0.2 \mu M$ for ST11 and ST15, $1.2 \mu M$ for Fli15, Typ04, ENTF, and ENTR) primer, $0.3 \mu \mathrm{L}$ (1.5 U) Taq DNA polymerase (First Base Asia) and sterile distilled water. The PCR reactions were conducted in a Veriti 96Well Thermal Cycler (Thermo Fisher Scientific, USA). Multiplex PCR conditions: initial denaturation at $94{ }^{\circ} \mathrm{C}$ for $2 \mathrm{~min}, 30$ cycles of denaturation at $94{ }^{\circ} \mathrm{C}$ for $45 \mathrm{~s}$, annealing at $53{ }^{\circ} \mathrm{C}$ for $1 \mathrm{~min}$, extension at $72{ }^{\circ} \mathrm{C}$ for $1 \mathrm{~min}$, and a final extension at $72{ }^{\circ} \mathrm{C}$ for $7 \mathrm{~min}$. PCR products were electrophoresed and visualised under UV light using a UV transilluminator.

\section{DETERMINATION OF ANTIBIOTIC SUSCEPTIBILITY PROFILE}

Antibiotic susceptibility test was conducted by using disc diffusion method as described by the Clinical and Laboratory Standards Institute (CLSI 2012). Culture of microorganisms grown at $37^{\circ} \mathrm{C}$ for $24 \mathrm{~h}$ in $10 \mathrm{~mL}$ tryptic soy broth (Merck, Darmstadt, Germany) were spread onto Mueller-Hinton agar plates (Merck, Darmstadt, Germany) by using sterile cotton swab and left to dry for 2 to $4 \mathrm{~min}$. The antibiotic discs were then placed onto the agar spread with bacterial culture by using a sterile forceps and the plates were incubated for $24 \mathrm{~h}$ at $37^{\circ} \mathrm{C}$. Antibiotics tested were erythromycin $(15 \mu \mathrm{g})$, penicillin $(10 \mu \mathrm{g})$, chloramphenicol $(30 \mu \mathrm{g})$, sulfamethoxazoletrimethoprim $(25 \mu \mathrm{g})$, tetracycline $(30 \mu \mathrm{g})$, amoxicillin $(25 \mu \mathrm{g})$, ampicillin $(10 \mu \mathrm{g})$, cephalexin $(30 \mu \mathrm{g})$, cefoxitin (30 $\mu \mathrm{g})$, cefotaxime $(30 \mu \mathrm{g})$, and ceftriaxone $(30 \mu \mathrm{g})$. These antibiotics were chosen in this study because they are used as treatments for Salmonella infection in clinical settings. Susceptibility of isolates to antibiotics were determined by measuring diameter of inhibition zone based on CLSI (2012) guidelines. The multiple resistance index (MAR) was determined from the formula: $a / b$, where a represents the number of antibiotics resistant to a specific isolate and $b$ the total number of antibiotics tested (Krumperman 1983).

\section{RESULTS AND DISCUSSION}

\section{DETECTION AND CONFIRMATION OF Salmonella spp. ISOLATES}

From the 20 samples examined, only 12 samples exhibited black colonies on XLD agar. These presumptive Salmonella spp. colonies were subjected to biochemical test using Microgen GN-ID A+B system. Results showed that 7 out of 12 isolates were identified as Salmonella enterica Group 1, whereas the other five were identified as Aeromonas hydrophila and Burkholderia pseudomallei (Table 2). Salmonella spp. positive samples were obtained from the raw chicken thigh (A1), tables (M2 and M3), cutting knife (P1), chopping board (PP1 and PP2), and container (BA). The other five samples were Aeromonas hydrophila collected from a table (M1) and raw chicken wing (A3), and Burkholderia pseudomallei which was collected from chopping board (PP3 and PP4) and one of the cages (SA). Identification of Salmonella spp. isolates using the polymerase chain reaction (PCR) method further confirms the obtained result. Specific gene targeting ST11 and ST15 gene in random sequences showed Salmonella spp. which produced a PCR product 429 bp in size (Figure 1). Detection of Salmonella spp. through multiplex PCR showed that 7 isolates tested were Salmonella spp. based on the amplification of targeted genes ST11 and ST15 (Aabo et al. 1992), suggesting that ST11 and ST15 are the most sensitive primers that can 
be used for rapid molecular detection of Salmonella spp. for screening food contamination with Salmonella spp. However, no PCR products were amplified for detection of Salmonella Enteritidis and Salmonella Typhimurium, suggesting that all 7 isolates were neither serotype Enteritidis nor Typhimurium. Interestingly, emerging pathogens Aeromonas hydrophila and Bulkholderia pseudomallei were also isolated in this study. Multidrug resistant $A$. hydophila strains have been isolated from chicken meats collected at retail market, suggesting the future healthcare concern if not controlled properly (Elbehiry et al. 2019). A. hydrophila resistant to multiple antibiotics have been isolated from freshwater tilapia collected from wet market in Kuala Lumpur, Malaysia (Son et al. 1997). B. pseudomallei is an emerging pathogen that causes melliodosis and is usually found in soil. However, B. pseudomallei has been isolated from wild birds in Australia (Hampton et al. 2011). The presence of $B$. pseudomallei was recorded in water source of small ruminant farm in Malaysia (Musa et al. 2018). The presence of $B$. pseudomallei in raw meats suggested previous contact of the meats with soil either prior to slaughter or post slaughter process.

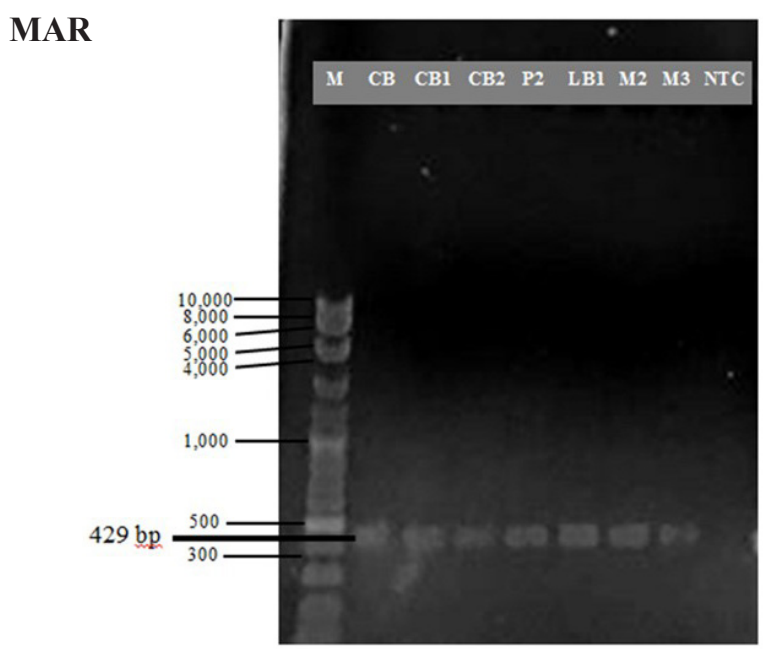

FIGURE 1. Agarose gel electrophoresis of PCR product for detection of Salmonella spp. by targeting random sequences. Lane 1 represents DNA marker of $100 \mathrm{bp}$ and lanes 2 to 8 represent amplified products (429 bp)

M: DNA Marker; CB: Chopping board; CB1: Chopping board 1; CB2: Chopping board 2; LB; Chicken meat; P2: Knife; M1: Table 1; M2: Table 2

TABLE 1. List of primers for gene amplification

\begin{tabular}{|c|c|c|c|}
\hline Primer & Nucleotide sequence 5' to 3 ' & Product size (bp) & Reference \\
\hline \multirow[t]{2}{*}{ ST11 } & GCCAA CCATT GCTAA ATTGG CGCA & & \\
\hline & & 429 & Soumet et al. (1999) \\
\hline ST15 & GGTAG AAATT CCCAG CGGGT ACTGG & & \\
\hline \multirow[t]{2}{*}{ ENTF } & TGTGT TTTAT CTGAT GCAAG AGG & & \\
\hline & & 304 & Alvarez et al. (2004) \\
\hline ENTR & TGAAC TACGT TCGTT CTTCT GG & & \\
\hline \multirow[t]{2}{*}{ Fli15 } & CGGTG TTGCC CAGGT TGGTA AT & & \\
\hline & & 620 & Soumet et al. (1999) \\
\hline Typ04 & ACTGG TAAAG ATGGC T & & \\
\hline
\end{tabular}


TABLE 2. Biochemical test results of the isolates from raw chicken meat and meat contact surfaces using system Microgen GN-ID $\mathrm{A}+\mathrm{B}$

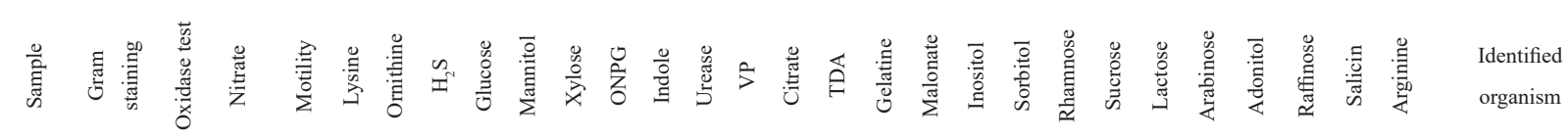

\begin{tabular}{|c|c|c|c|c|c|c|c|c|c|c|c|c|c|c|c|c|c|c|c|c|c|c|c|c|c|c|c|c|c|}
\hline BA & -ve rod & - & NA & + & + & + & + & + & + & + & - & - & - & + & + & - & - & - & - & + & + & - & - & + & - & - & - & + & S. enterica group 1 \\
\hline M1 & -ve rod & + & + & + & + & - & + & + & + & + & - & - & - & + & - & - & - & - & - & + & + & - & - & + & - & - & - & + & A. hydrophila \\
\hline M2 & -ve rod & - & NA & + & + & + & + & + & + & + & - & - & - & + & - & - & - & - & - & + & + & - & - & + & - & - & - & + & S. enterica group 1 \\
\hline M3 & -ve rod & - & NA & + & + & - & + & + & + & + & - & - & - & + & + & - & - & - & - & + & + & - & - & + & - & - & - & + & S. enterica group 1 \\
\hline PP1 & - ve rod & - & NA & + & + & + & + & + & + & + & - & - & - & + & + & - & - & - & + & + & + & - & - & + & - & - & - & + & S. enterica group 1 \\
\hline PP2 & -ve rod & - & NA & + & + & - & + & + & + & + & - & - & - & + & - & - & - & - & + & + & + & - & - & + & - & - & - & + & S. enterica group 1 \\
\hline PP3 & -ve rod & + & + & + & + & - & + & + & + & + & - & - & - & + & - & - & - & - & + & + & + & - & - & + & - & - & - & + & B. pseudomonallei \\
\hline PP4 & -ve rod & + & + & + & + & - & + & + & + & + & - & - & - & + & - & - & - & - & + & + & + & - & - & + & - & - & - & + & B. pseudomonallei \\
\hline $\mathrm{P} 2$ & -ve rod & - & NA & + & + & + & + & + & + & + & - & - & - & + & - & - & - & - & + & + & + & - & - & + & - & - & - & + & S. enterica group 1 \\
\hline $\mathrm{A} 1$ & -ve rod & - & NA & + & + & + & + & + & + & + & - & + & + & + & - & + & + & - & - & - & + & - & - & + & - & - & - & + & S. enterica group 1 \\
\hline A3 & -ve rod & + & + & + & + & - & + & + & + & + & - & - & - & + & - & - & - & - & - & + & + & - & - & + & - & - & - & + & A. hydrophila \\
\hline SA & -ve rod & + & + & + & + & - & + & + & + & + & - & - & - & + & - & - & - & - & + & + & + & - & - & + & - & - & - & + & B. pseudomonallei \\
\hline
\end{tabular}

- : Negative; + :Positive; NA, not available; $\mathrm{H}_{2} \mathrm{~S}$; Hydrogen sulphide; VP, Voges-Proskauer; TDA, Tryptophan Deaminase;

BA, container; M1, table 1; M2, table 2; M3, table 3; PP1, chopping board 1; PP2, chopping board 2; PP3, chopping board 3; PP4, chopping board 4; P2, knive; $\mathrm{t}$

A1,chicken thigh; A3,chicken wing; SA;cage

TABLE 3. Antibiotic resistance profile and multiple antibiotic resistance (MAR) index of Salmonella spp. isolates

\begin{tabular}{ccc}
\hline Isolate ID & Antibiotic resistance profile & MAR $^{1}$ index \\
\hline CB & C, E, TET, P & 0.36 \\
M2 & C, E, TET, P & 0.36 \\
M3 & C, E, TET, P & 0.36 \\
CB1 & C, E, TET, P, SXT, AML, AMP & 0.64 \\
CB2 & C, E, TET, P, SXT, AML, AMP & 0.64 \\
LB1 & C, E, TET, P, SXT, AML, AMP & 0.64 \\
P2 & C, E, TET, P, SXT, AML, AMP, CTX, CL, FDX, CRO & 1.00 \\
\hline
\end{tabular}

${ }^{1}$ Multiple antibiotic resistance (MAR) index

CB : Chopping board; CB1 : Chopping board 1; CB2 : Chopping board 2; LB; Chicken meat; P2 : Knife; M1 : Table 1; M2 : Table 2

P : Penicillin; C : Chloramphenicol; E : Erythromycin; SXT : Sulfamethoxazole-trimethoprim; TE : Tetracycline; AML : Amoxycilin; AMP : Ampicilin; CL : Cephalexin; FDX : Cefoxitin; CTX : Cefotaxime; CRO : Ceftriaxone 


\section{DETERMINATION OF ANTIBIOTIC SUSCEPTIBILITY} PROFILE

Table 3 shows the antibiotic susceptibility profile of 7 Salmonella spp. isolates towards selected antibiotics. All 7 isolates were resistant towards erythromycin (E15), penicillin (P10), chloramphenicol (C30) and tetracycline (TE30). No antibiotic tested in this study was $100 \%$ effective against Salmonella isolates (Table 3). There were 4 isolates (CB1, CB2, and LB1) that showed resistance towards trimethoprim-sulfamethoxazole (SXT25), amoxicillin (AML25) and ampicillin (AMP10). However, sensitivity was recorded for cephalexin, cefoxitin, cefotaxime and ceftriaxone. Interestingly, one isolate (P2) was resistant towards cephalexin (CL30), cefoxitin (FDX30), cefotaxime (CTX30) and ceftriaxone (CRO30).

The lowest MAR index was 0.36 , while the highest was 1.00. All Salmonella spp. isolates were multidrugresistant, in which all of them were resistant to more than 3 antibiotics (Table 3). A total of three isolates (CB, M2 and M3) were resistant to 4 antibiotics (MAR=0.36) while another 3 isolates $(\mathrm{CB} 1, \mathrm{CB} 2$ and $\mathrm{LB} 1)$ were resistant to 7 antibiotics $(\mathrm{MAR}=0.64)$. Meanwhile, one isolate $(\mathrm{P} 2)$ was resistant to all antibiotics tested $(\mathrm{MAR}=1.00)$. In our study, high resistance of Salmonella spp. to penicillin, erythromycin, tetracycline, and chloramphenicol suggest that resistance rates of Salmonella spp. against these antibiotics are increasing in this region. Resistance to erythromycin and penicillin was commonly observed in retail meat products (Sallam et al. 2014). Previous study found that penicillin resistance in poultry and poultry environment was $100 \%$ (Singh et al. 2013). These characteristics of resistance can arise from inadequate use or overuse of a particular antimicrobial in farming practices. In agriculture, overuse of antibiotics leads to the transmission of antibiotic-resistant microbes from agriculture to humans through the transfer of resistance genes between microbes (Chang et al. 2015).

All Salmonella isolates from this study were resistant to tetracycline. However, previous studies showed that Salmonella isolated from raw chicken meat collected from Malaysian retail markets was $100 \%$ sensitive to tetracycline (Thung et al. 2018, 2016). This discrepancy can be explained by the location of samples collected, in which our study collected the samples from a wet market in Chow Kit which is located at the heart of Kuala Lumpur while previous studies collected the samples from various hypermarkets in Selangor. Differences in food hygienic practice between hypermarkets and wet market must have contributed to different rate of antibiotic-resistant bacteria transmission in those places. This also raises the question of hygienic practice of food handling in wet market. Furthermore, meats are stored at room temperature in wet market while in hypermarket, they are stored at cold temperature $\left(2-8^{\circ} \mathrm{C}\right)$. P2 isolate that was isolated from the knife showed resistance to all antibiotics tested. Emergence of extensively drugresistant Salmonella, which is resistant to third-generation cephalosphorins and fluoroquinolone, has been observed in parts of Asia and Africa. These strains pose a serious healthcare problem because of the limited availability of treatment options (Klemm et al. 2018). Isolate P2 from this study was resistant to all antibiotics tested, including cefotaxime (third-generation cephalosphorin). However, we did not examine the resistance of this isolate against fluoroquinolone. Therefore, confirmation of whether this strain is extensively drug-resistant Salmonella could not be confirmed. Future study to screen the emergence of extensively drug resistance Salmonella from wet markets should be conducted.

All Salmonella isolates found in this study were resistant to at least 4 antibiotics, thus, were multidrugresistant. These multidrug-resistant salmonella strains can be transmitted to humans via the ingestion of infected chicken meat and would possibly cause difficulties in the treatment of salmonella in Malaysia. The emergence of Salmonella serovars with a high MAR index indicates that these serovars originated in environments where antimicrobials are commonly used as therapeutic or as animal feed growth promoters (Krumperman 1983; Singh et al. 2013). In addition, genetic and biochemical mechanisms may have contributed to the emergence of salmonella MDR strains, thus preserving their genes for drug resistance and increasing their survival.

This study showed that the wet market served as the main source of Salmonella transmission in humans. The high percentage of multidrug-resistant Salmonella spp. isolated from the wet market poses public healthcare concern in the future if not appropriately controlled. Control of transmission of multidrug-resistant Salmonella from raw chicken meat requires stringent hygienic practice at the wet market. Thus, it is necessary to develop effective intervention strategies to ascertain the safety of our food supplies. Further studies to elucidate the antimicrobial resistance mechanism in Salmonella spp. should be conducted.

\section{ACKNOWLEDGEMENTS}

This research was funded by Universiti Kebangsaan Malaysia under grant no. GUP-2018-119. The authors would like to thank Medical Laboratory Technology (MLT) staff from Programme of Biomedical Science 
Universiti Kebangsaan Malaysia, Kuala Lumpur (UKMKL) for their kind assistance during this study.

\section{REFERENCES}

Aabo, S., Thomas, A., Hall, M.L., Smith, H.R. \& Olsen, J.E. 1992. Evaluation of a Salmonella-specific DNA probe by colony hybridisation using non-isotopic and isotopic labelling. APMIS 100(7-12): 623-628.

Abdalla, M.A., Siuman, S.E. \& Alian, Y.Y.H.A. 2009. Microbial contamination of sheep carcasses at El Kadero slaughterhouse in Khartoum State. The Sudan Journal of Veterinary Science and Animal Husbandry 48(1\&2): 51-56.

Chai, L.C., Robin, T., Ragavan, U.M., Gunsalam, J.W., Bakar, F.A., Ghazali, F.M., Radu, S. \& Kumar, M.P. 2007. Thermophilic Campylobacter spp. in salad vegetables in Malaysia. International Journal of Food Microbiology 117(1): 106-111.

Chang, Q., Wang, W., Regev-Yochay, G., Lipsitch, M. \& Hanage, W.P. 2015. Antibiotics in agriculture and the risk to human health: How worried should we be? Evolutionary Applications 8(3): 240-247.

Chong, E.S., Abu Bakar, N.F., Zin, N.M. \& Zulfakar, S.S. 2017. Presence of Salmonella spp. on beef carcasses and meat contact surfaces at local abattoirs in Selangor, Malaysia. Jurnal Sains Kesihatan Malaysia 15(2): 115-119.

Clinical and Laboratory Standards Institute (CLSI). 2012. Performance standards for antimicrobial susceptibility testing: Twenty-second informational supplement. Pennsylvania: Clinical and Laboratory Standards Institute.

Crump, J.A., Sjölund-Karlsson, M., Gordon, M.A. \& Parry, C.M. 2015. Epidemiology, clinical presentation, laboratory diagnosis, antimicrobial resistance, and antimicrobial management of invasive Salmonella infections. Clinical Microbiology Reviews 28(4): 901-937.

Department of Veterinary Services Malaysia. 2020. Malaysia: Perangkaan Ternakan. Ministry of Agriculture and Food Industry. http://www.dvs.gov.my/dvs/resources/user_1/2019/ BP/Perangkaan\%20Ternakan/1)_Malaysia_Perangkaan_ Ternakan _.pdf. Accessed on 4th July 2021.

Elbehiry, A., Marzouk, E., Abdeen, E., Al-Dubaib, M., Alsayeqh, A., Ibrahem, M., Hamada, M., Alenzi, A., Moussa, I. \& Hemeg, H.A. 2019. Proteomic characterization and discrimination of Aeromonas species recovered from meat and water samples with a spotlight on the antimicrobial resistance of Aeromonas hydrophila. Microbiologyopen 8(11): e782.

Hampton, V., Kaestli, M., Mayo, M., Choy, J.L., Harrington, G., Richardson, L., Benedict, S., Noske, R., Garnett, S.T., Godoy, D., Spratt, B.G. \& Currie, B.J. 2011. Melioidosis in birds and Burkholderia pseudomallei dispersal, Australia. Emerging Infectious Diseases 17(7): 1310-1312.

Ishola, D.O. \& Taiwo, A.G. 2014. Frozen retail poultry meat contact surfaces as sources of Salmonella and Escherichia coli contamination in Ibadan, Oyo State, Nigeria. American Journal of Infectious Diseases and Microbiology 2: 81-85.
Jayaraman, K., Munira, H., Chowdhury, D. \& Iranmanesh, M. 2013. The preference and consumption of chicken lovers with race as a moderator - An empirical study in Malaysia. International Food Research Journal 20(1): 165-174.

Klemm, E.J., Shakoor, S., Page, A.J., Qamar, F.N., Judge, K., Saeed, D.K., Wong, V.K., Dallman, T.J., Nair, S., Baker, S., Shaheen, G., Qureshi, S., Yousafzai, M.T., Saleem, M.K., Hasan, Z., Dougan. G. \& Hasan, R. 2018. Emergence of an extensively drug-resistant Salmonella enterica serovar Typhi clone harboring a promiscuous plasmid encoding resistance to fluoroquinolones and third-generation cephalosporins. mBio 9(1): e00105-18.

Krumperman, P.H. 1983. Multiple antibiotic resistance indexing of Escherichia coli to identify high-risk sources of fecal contamination of foods. Applied and Environmental Microbiology 46(1): 165-170.

Li, Y., Lv, M., Su, C., Long, S., Zhang, W., Conway, K.L., Li, W., Xavier, R.J. \& Shi, H.N. 2017. P40phox-deficient mice exhibit impaired bacterial clearance and enhanced proinflammatory responses during Salmonella Enterica serovar Typhimurium infection. Frontiers in Immunology 8: 1270.

Majowicz, S.E., Musto, J., Scallan, E., Angulo, F.J., Kirk, M., O’Brien, S.J., Jones, T.F., Fazil, A., Hoekstra, R.M. \& International Collaboration on Enteric Disease 'Burden of Illness' Studies. 2010. The global burden of non-typhoidal Salmonella gastroenteritis. Clinical Infectious Diseases 50(6): 882-889.

Mead, G.C. 2000. Fresh and further processed poultry. In The Microbiological Safety and Quality of Food, edited by Lund, B.M., Baird Parker, T.C. \& Gould, G.W. Maryland: Aspen Publishers Gaithersburg. pp. 445-447.

Montville, T.J. \& Matthews, K.R. 2008. Food Microbiology: An Introduction. 2nd ed. Washington: ASM Press.

Muhammad, E.N., Abdul Mutalip, M.H., Hasim, M.H., Paiwai, F., Pan, S., Mahmud, M.A.F., Yeop, N., Tee, G.H., Senin, A.A. \& Aris, T. 2020. The burden of typhoid fever in Klang Valley, Malaysia, 2011-2015. BMC Infectious Disease 20(1): 843.

Musa, H.I., Hassan, L., Shamsuddin, Z.H., Panchadcharam, C., Zakaria, Z. \& Aziz, S.A. 2018. Physicochemical properties associated with the presence of Burkholderia pseudomallei in small ruminant farm water supplies in Peninsular Malaysia. Environmental Monitoring and Assessment 190(4): 241.

Najwa, M.S., Rukiyadi, Y., Ubong, A., Loo, Y.Y., Chang, W.S., Lye, Y.L., Thung, T.Y., Aimi, S.A., Malcolm, T.T.H., Goh, S.G., Kuan, C.H., Yoshitsugu, N., Nishibuchi, M. \& Son, R. 2015. Quantification and antibiotic susceptibility of Salmonella spp., Salmonella Enteritidis and Salmonella Typhimurium in raw vegetables (ulam). International Food Research Journal 22(5): 1761-1769.

Saad, M.S., Edris, A.M., Shaltout, F.A. \& Edris-Shima, N. 2011. Isolation and identification of Salmonellae and E.coli from meat and poultry cuts by using multiplex PCR. Benha Veterinary Medical Journal 2: 152-160.

Sallam, K.I., Mohammed, M.A., Hassan, M.A. \& Tomura, T. 2014. Prevalence, molecular identification and antimicrobial resistance profile of Salmonella serovars isolated from retail beef products in Mansoura, Egypt. Food Control 38: 209-214 
Singh, R., Yadav, A.S., Tripathi, V. \& Singh, R.P. 2013. Antimicrobial resistance profile of Salmonella present in poultry and poultry environment in north India. Food Control 33: 545-548.

Son, R., Rusul, G., Sahilah, A.M., Zainuri, A., Raha, A.R. \& Salmah, I. 1997. Antibiotic resistance and plasmid profile of Aeromonas hydrophila isolates from cultured fish, Telapia (Telapia mossambica). Letters in Applied Microbiology 24(6): 479-482.

Su, L.H., Chiu, C.H., Chu, C. \& Ou, J.T. 2004. Antimicrobial resistance in nontyphoid Salmonella serotypes: A global challenge. Clinical Infectious Diseases: An Official Publication of the Infectious Diseases Society of America 39: 546-551.

Thung, T.Y., Mahyudin, N.A., Basri, D.F., Wan Mohamed Radzi, C.W.J., Nakaguchi, Y., Nishibuchi, M. \& Radu, S. 2016. Prevalence and antibiotic resistance of Salmonella Enteritidis and Salmonella Typhimurium in raw chicken meat at retail markets in Malaysia. Poultry Science 95(8): 1888-1893.

Thung, T.Y., Radu, S., Mahyudin, N.A., Rukayadi, Y., Zakaria, Z., Mazlan, N., Tan, B.H., Lee, E., Yeoh, S.L., Chin, Y.Z., Tan, C.W., Kuan, C.H., Basri, D.F. \& Wan Mohamed Radzi, C.W.J. 2018. Prevalence, virulence genes and antimicrobial resistance profiles of Salmonella serovars from retail beef in Selangor, Malaysia. Frontiers in Microbiology 8: 2697.

Zulfakar, S.S., Sahani, M. \& Abd Hamid, N.H. 2018. Microbiological assessment of food contact surfaces in residential college cafeterias at a local university in Malaysia. Malaysian Journal of Health Sciences 16(2): 33-38.
Asif Sukri

Integrative Pharmacogenomics Institute (iPROMISE)

Universiti Teknologi MARA (UiTM)

Puncak Alam Campus

42300 Bandar Puncak Alam, Selangor Darul Ehsan

Malaysia

Siti Shahara Zulfakar

Environmental Health \& Industrial Safety Programme

Centre for Toxicology and Health Risk Studies

Faculty of Health Sciences

Universiti Kebangsaan Malaysia

50300 Kuala Lumpur, Federal Territory

Malaysia

Illya Syahirah Mohd Taib, Nurul Fathiah Omar \& Noraziah Mohamad Zin*

Programme of Biomedical Science

Centre for Diagnostic, Therapeutic, \& Investigative Studies

Faculty of Health Sciences

Universiti Kebangsaan Malaysia

50300 Kuala Lumpur, Federal Territory

Malaysia

*Corresponding author; email: noraziah.zin@ukm.edu.my

Received: 29 September 2021

Accepted: 2 December 2021 